\title{
Induction and mechanism of HeLa cell apoptosis by 9-oxo-10, 11-dehydroageraphorone from Eupatorium adenophorum
}

\author{
FEI LIAO ${ }^{1,2}$, YANCHUN HU ${ }^{1}$, LEI WU ${ }^{1}$, HUI TAN ${ }^{1}$, BIAO LUO ${ }^{1}$, YAJUN HE $^{1}$, YAN QIAO ${ }^{1}$, \\ QUAN MO $^{1}$, YA WANG ${ }^{1}$, ZHICAI ZUO ${ }^{1}$, JUNLIANG DENG ${ }^{1}$ and YAHUI WEI ${ }^{3}$

\begin{abstract}
${ }^{1}$ Key Laboratory of Animal Disease and Human Health of Sichuan Province, College of Veterinary Medicine, Sichuan Guizhou, Kaili 556000; ${ }^{3}$ Key Laboratory of Resource Biology and Biotechnology in Western China,

School of Life Science, Northwest University, Xi'an 710069, P.R. China
\end{abstract} \\ Agricultural University, Sichuan, Wenjiang 611130; ${ }^{2}$ Animal Epidemic Disease Control Center of Qiandongnan Prefectural,
}

Received September 29, 2014; Accepted December 2, 2014

DOI: $10.3892 /$ or.2015.3778

\begin{abstract}
Oxo-10, 11-dehydroageraphorone (euptox A), a cadenine sesquiterpene, is the main toxin from Eupatorium adenophorum. The aim of the present study was to examine the induction and mechanism of HeLa cell apoptosis by euptox A. The apoptosis-inducing effect of the euptox A on HeLa cells was examined by MTT assay. The underlying mechanism was analyzed by flow cytometry and quantitative PCR. Flow cytometry results suggested that euptox A effectively inhibited the proliferation of HeLa cells, arrested the cell cycle transition from $\mathrm{S}$ to $\mathrm{G} 2 / \mathrm{M}$ phase, did not continue to complete the cell cycle activity (mainly from 4 times and mitosis), and induced cell proliferation. The RT-qPCR detection results showed that euptox $\mathrm{A}$ induced apoptosis by improving the gene expression level of apoptotic proteases such as caspase-10 in HeLa cells. Its mechanism of action was associated with the upregulation of apoptotic gene expression and arresting of the cell cycle.
\end{abstract}

\section{Introduction}

Eupatorium adenophorum (E.adenophorum), native to Mexico and Costa Rica of Central America, is a worldwide noxious invasive weed (1). After its introduction as an ornamental plant to the USA in the 1960s, it has spread worldwide (2), as a non-native species to India, New Zealand, and Australia. In China, it first invaded southern regions of Yunnan Province

Correspondence to: Dr Yanchun Hu, Key Laboratory of Animal Disease and Human Health of Sichuan Province, College of Veterinary Medicine, Sichuan Agricultural University, 211 Huimin Road, Sichuan, Wenjiang 611130, P.R. China

E-mail: yanchunhu@126.com

Dr Yahui Wei, Key Laboratory of Resource Biology and Biotechnology in Western China, School of Life Science, Northwest University, Xi'an 710069, P.R. China

E-mail:wyh1960@126.com

Key words: 9-oxo-10, 11-dehydroageraphorone, Eupatorium adenophorum, apoptosis, mechanism from Burma in the 1940s (3). At present, E. adenophorum can be found in Chongqing, Yunnan, Sichuan, Guizhou, Tibet, Guangxi, Taiwan and Hubei provinces. The annual spreading rate of E. adenophorum is estimated to be $10-60 \mathrm{~km}$ from south to north and from west to east in China (4). It is considered a threat to the local economy and biodiversity. However, as has been reported, several compounds have been separated and characterized from the E. adenophorum stem, flowers and leaves, including hemiterpenes, sterides, triterpenes, flavonoid and phenylpropanoids phenol, which have extensive biological activity, such as anti-inflammatory potential (5), acaricidal $(6,7)$ and antioxidant activity (8). E. adenophorum can be used as a food (9), medical (10), and chemical material resource (11).

9-Oxo-10, 11-dehydroageraphorone (euptox A), a cadenine sesquiterpene, is the main toxin from E. adenophorum. Results of previous studies have shown that the euptox A from E. adenophorum exhibited hepatotoxicity (12) and allelopathy (13). Our laboratory has proved that euptox A exhibited highly acaricidal activity for S. scabiei and P.cuniculi in vitro (14) and euptox A presented significantly antitumor activity against the human lung cancer A549, HeLa and Hep-2 cell lines in vitro in a dose-dependent manner (15).

In the present study, MTT, flow cytometry and RT-PCR were used to detect the change of indices prior to and following drug action, followed by a comparison of the availability of different methods.

\section{Materials and methods}

Materials. Euptox A was provided by the laboratory of biotoxin and molecular toxicology of Sichun Agriculture University, China. The purity of the toxin we extracted was $>96 \%$ (16).

Cell cultures. HeLa cell lines were cultured at $37^{\circ} \mathrm{C}$ in a humidified atmosphere of $5 \% \mathrm{CO}_{2}$ in DMEM supplemented with $10 \%$ FCS, glutamine, $100 \mathrm{U} / \mathrm{ml}$ penicillin, and $100 \mu \mathrm{g} / \mathrm{ml}$ streptomycin. Cell cultures were divided every 3 days.

Colorimetric MTT assay for cell proliferation. The cytotoxicity of euptox A against HeLa cells was measured by the MTT assay (17). The HeLa cell line was maintained in DMEM supple- 
Table I. PCR primers.

\begin{tabular}{llc}
\hline Primer name & \multicolumn{1}{c}{ Primer sequence } & $\begin{array}{c}\text { Size of PCR } \\
\text { product (bp) }\end{array}$ \\
\hline Caspase-10 (F) & GTATCAGGCTACCCAGTCC & \\
Caspase-10 (R) & CAGATCAAGCTCCACCAA & 192 \\
Caspase-3 (F) & GGTTCATCCAGTCGCTTTG & \\
Caspase-3 (R) & CTCTGTTGCCACCTTTCG & 97 \\
$\beta$-actin (F) & GTTGCGTTACACCCTTTC & \\
$\beta$-actin (R) & CTGTCACCTTCACCGTTC & 151 \\
\hline
\end{tabular}

mented with $10 \%$ fetal bovine serum, $100 \mathrm{mU} / 1$ streptomycin, and $100 \mathrm{mU} / 1$ penicillin at $37^{\circ} \mathrm{C}$ in a humidified atmosphere of $5 \% \mathrm{CO}_{2}$. Cells $\left(3 \times 10^{3} /\right.$ well) in their exponential growth phase were seeded into each well of a 96-well flat-bottomed culture plate and incubated for $24 \mathrm{~h}$. HeLa cells were incubated with the samples (euptox A) at concentrations of $0,0.25,0.5,1$ and $2 \mu \mathrm{g} / \mathrm{ml}$. After $48 \mathrm{~h}, 20 \mu \mathrm{l}$ of $5 \mu \mathrm{g} / \mathrm{ml}$ of MTT was added to each well and incubated for another $4 \mathrm{~h}$. Following removal of the culture media, $150 \mu \mathrm{l}$ of DMSO were added to each well. Absorbance at $490 \mathrm{~nm}$ was detected by a microplate ELISA reader. 5-Fu was treated as a positive control. The inhibition rate was calculated according to the formula:

Growth inhibition rate $(\%)=\left(1-\frac{\text { Absorbance of experimental group }}{\text { Absorbance of control group }}\right) \times 100 \%$

Flow cytometry. HeLa cells were plated at a density of $75 \times 10^{3} /$ well in $24-w e l l$ plates and grown with DMEM containing $10 \%$ FBS. The following day, euptox A was added at a concentration of $0,10,30$ and $50 \mu \mathrm{g} / \mathrm{ml}$, respectively, and the cells were incubated for $24 \mathrm{~h}$. 5-Fu was treated as a positive control for each incubation period. The HeLa cell cycle was assessed by flow cytometry analyzing DNA content in propidium iodide (PI)-stained cells. Briefly, the cells were collected with trypsin/EDTA, washed, incubated for $15 \mathrm{~min}$ with PI, and analyzed by flow cytometry.

RT-qPCR detection HeLa apoptotic gene expression. Logarithmic phase cells were divided into 3 groups, i.e., vehicle, experimental control (the concentration of euptox A was 0,10 , 30 and $50 \mu \mathrm{g} / \mathrm{ml}$, respectively) and positive control (5-Fu was treated as the positive control). The cells were extracted after $48 \mathrm{~h}$, then used to measure gene expression by RT-qPCR.

Total RNA was isolated from $10^{6}$ to $10^{7}$ cells in a growing phase using TRIzol (Aidlab, China) according to the manual. The RNA was then chloroform-extracted and precipitated with isopropanol. Synthesis of single-stranded cDNA from $5 \mu \mathrm{g}$ of RNA was performed according to the TUREscript 1st strand cDNA Synthesis Kit from Aidlab. Pairs of 5' and 3' primers used to amplify each type of cDNA are shown in Table I. The reaction conditions used were: $94^{\circ} \mathrm{C}, 55^{\circ} \mathrm{C}$ and $72^{\circ} \mathrm{C}$ for $1 \mathrm{~min}$ (40 amplification cycles were necessary to achieve exponential amplification in which product formation was proportional to starting cDNA). Relative gene expression was then defined as
Table II. Activation of HeLa cell lines exposed to different concentrations of euptox A.

\begin{tabular}{lccc}
\hline Treatment & $\begin{array}{c}\text { Concentration } \\
(\mathrm{mg} / \mathrm{ml})\end{array}$ & $\begin{array}{c}\text { OD }(490 \mathrm{~nm}) \\
\text { mean } \pm \mathrm{SE}\end{array}$ & $\begin{array}{c}\text { Inhibition } \\
\text { ratio (\%) }\end{array}$ \\
\hline HeLa & & & \\
Control & - & $2.790 \pm 0.226^{\mathrm{a}}$ & 0 \\
$5-\mathrm{Fu}$ & 1 & $0.487 \pm 0.064^{\mathrm{b}, \mathrm{c}}$ & 82.54 \\
Euptox A & 0.25 & $2.201 \pm 0.393^{\mathrm{d}}$ & 21.09 \\
& 0.5 & $0.884 \pm 0.226^{\mathrm{b}}$ & 68.30 \\
& 1 & $0.218 \pm 0.024^{\mathrm{c}}$ & 92.16 \\
\hline
\end{tabular}

${ }^{\mathrm{a}-\mathrm{c}}$ Difference between data is significant $(\mathrm{P}<0.01)$. ${ }^{\mathrm{d}}$ Difference between data is significant $(\mathrm{P}<0.05)$.

Table III. Effect of euptox A on the cell cycle of HeLa cells (mean $\pm \mathrm{SD}, \mathrm{n}=3$ ).

\begin{tabular}{rccl}
\hline & G0/G1 phase & S phase & G2/M phase \\
\hline $0 \mu / \mathrm{ml}$ & $47.533 \pm 1.783^{\mathrm{b}}$ & $31.280 \pm 2.779^{\mathrm{d}}$ & $21.190 \pm 1.008^{\mathrm{a}, \mathrm{e}}$ \\
$10 \mu / \mathrm{ml}$ & $36.876 \pm 2.392^{\mathrm{c}}$ & $40.936 \pm 1.518^{\mathrm{c}}$ & $22.190 \pm 3.419^{\mathrm{a}}$ \\
$30 \mu / \mathrm{ml}$ & $34.093 \pm 2.494^{\mathrm{c}}$ & $48.583 \pm 1.519^{\mathrm{b}}$ & $17.320 \pm 0.979^{\mathrm{e}}$ \\
$50 \mu / \mathrm{ml}$ & $24.366 \pm 3.170^{\mathrm{d}}$ & $56.950 \pm 1.870^{\mathrm{a}}$ & $18.683 \pm 1.363^{\mathrm{e}, \mathrm{f}}$ \\
$5-\mathrm{Fu}$ & $54.553 \pm 2.201^{\mathrm{a}}$ & $29.603 \pm 1.745^{\mathrm{d}}$ & $15.843 \pm 0.813^{\mathrm{f}}$ \\
\hline
\end{tabular}

${ }^{\mathrm{a}-\mathrm{d}}$ Difference between data is significant $(\mathrm{P}<0.01)$. ${ }^{\mathrm{e}, \mathrm{f}}$ Difference between data is significant $(\mathrm{P}<0.05)$.

a ratio of target gene (caspase-10 and -3) expression vs. $\beta$-actin gene expression. Each ratio was determined independently three times.

Statistical analysis. Data are presented as mean \pm SEM and/or confidence interval. Statistical analyses were performed to compare the treated groups with the respective control group using a one-way analysis of variance (ANOVA) complemented with the Tukey-Kramer multiple comparison test with equal sample size. Computations were performed by employing the statistical software (SPSS, version 20.0) (18).

\section{Results}

In vitro cytotoxicity assay. To investigate the effects of euptox A treatment on cell viability, the endpoint of cytotoxicity (MTT) assays in the HeLa cell line was investigated and CR results are shown in Table II. The results showed euptox A had significant antitumor activity against the HeLa cell line in vitro in a dose-dependent manner. When the concentration of euptox A was at $500 \mu \mathrm{g} / \mathrm{ml}$, the percentage inhibition of HeLa cells was $68.30 \%$.

Flow cytometry. Morphological observation of HeLa cells treated with euptox A for $24 \mathrm{~h}$ is shown in Fig. 1. Euptox A effectively inhibited the proliferation of HeLa cells. The shape of Hela cells in the negative control group appeared as polyg- 

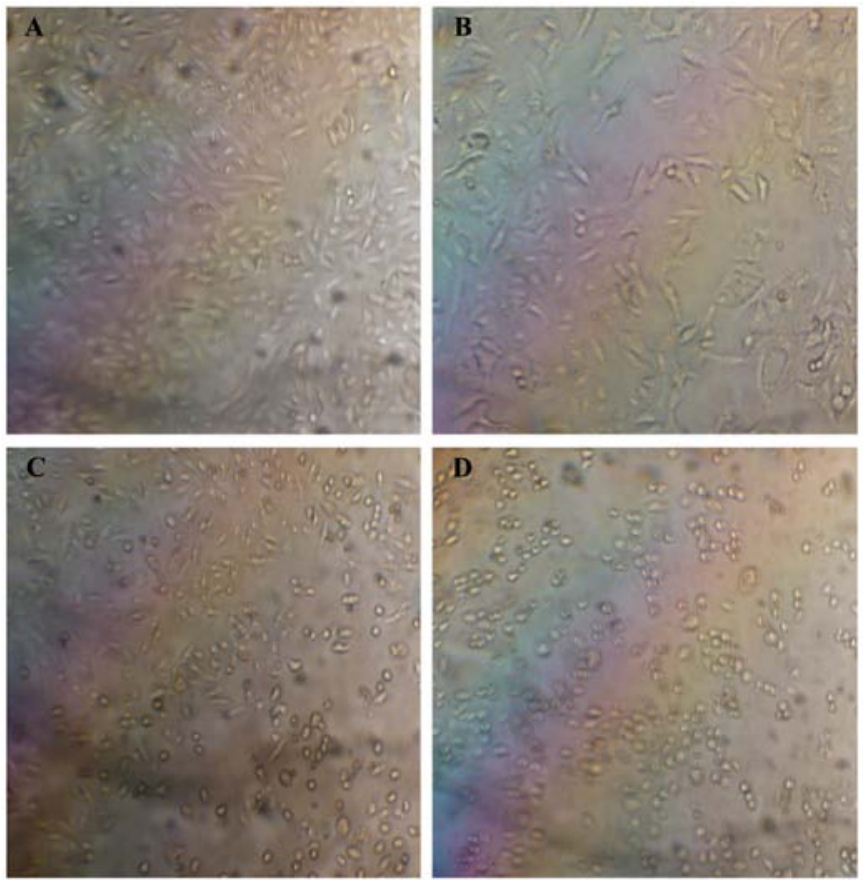

Figure 1. Morphological observation of HeLa cells treated with euptox A for $24 \mathrm{~h}$ (10x20). (A) $0 \mu / \mathrm{ml}$, (B) $10 \mu / \mathrm{ml}$, (C) $30 \mu / \mathrm{ml}$, (D) and $50 \mu / \mathrm{ml}$ euptox A.
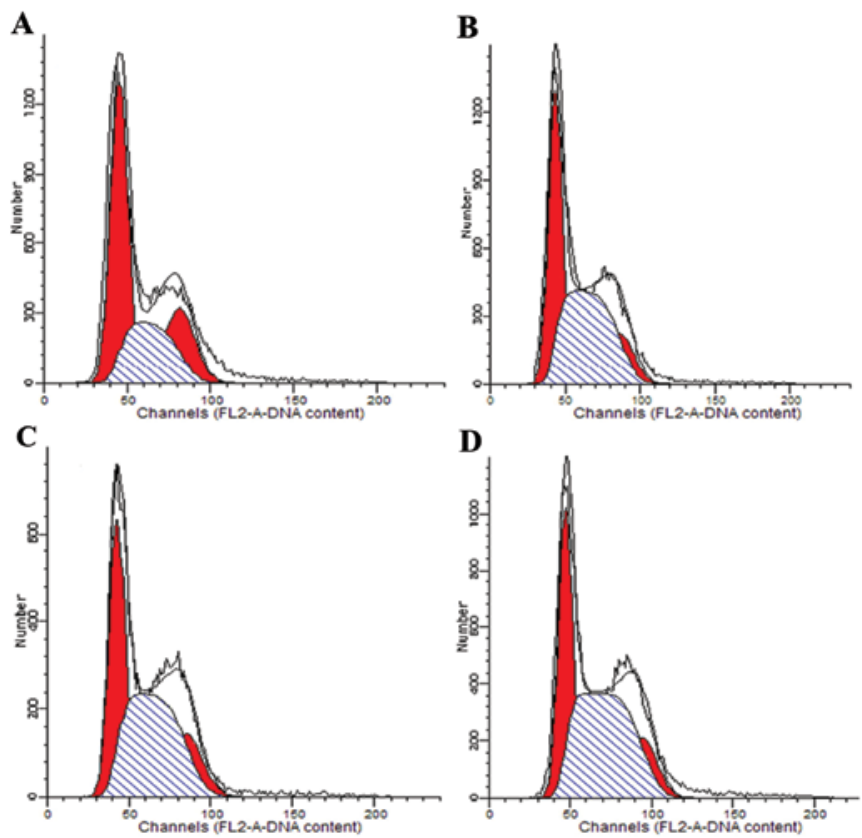

Figure 2. Effect of euptox A on the cell cycle of HeLa cells. (A) $0 \mu / \mathrm{ml}$, (B) $10 \mu / \mathrm{ml}$, (C) $30 \mu / \mathrm{ml}$ and (D) $50 \mu / \mathrm{ml}$ euptox A.

onal, were densely arranged, and firmly adherent (Fig. 1A). Compared with the negative control group, the cells were treated with euptox A at concentrations of 10,30 and $50 \mu \mathrm{g} / \mathrm{ml}$. The increase of the concentration of euptox A administration resulted in a gradual increase in cell suspension, a significant reduction in the number of adherent cells, which were sparsely arranged, fusiform, appeared long and had irregular protrusions. Membrane integrity was maintained, although characteristic apoptotoc changes were observed (Fig. 1B-D).

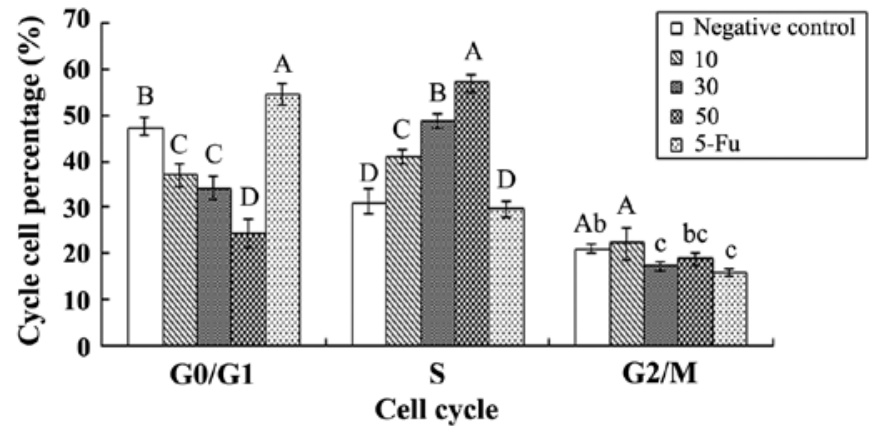

Figure 3. Effect of euptox A on the cell cycle of HeLa cells (mean $\pm \mathrm{SD}, \mathrm{n}=3$ ) 5-Fu: positive control group; negative control group: $0 \mu / \mathrm{ml}$ euptox $\mathrm{A}$; 10: $10 \mu \mathrm{g} / \mathrm{ml}$ of euptox A group; 30: $30 \mu \mathrm{g} / \mathrm{ml}$ of euptox A group group; 50: $50 \mu \mathrm{g} / \mathrm{ml}$ of euptox A group.

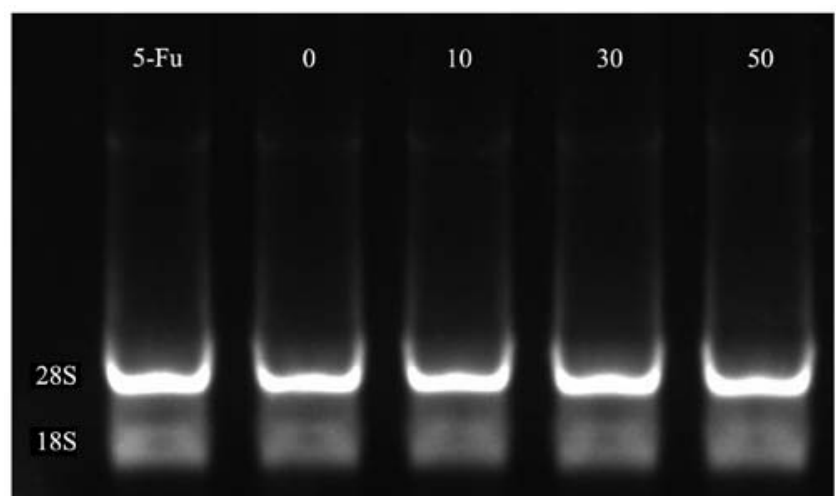

Figure 4. Total RNA was extracted from HeLa cells. 5-Fu: positive control group; 0: negative control group; 10: $10 \mu \mathrm{g} / \mathrm{ml}$ of euptox A group; 30: $30 \mu \mathrm{g} / \mathrm{ml}$ of euptox A group group and 50: $50 \mu \mathrm{g} / \mathrm{ml}$ of euptox A group.

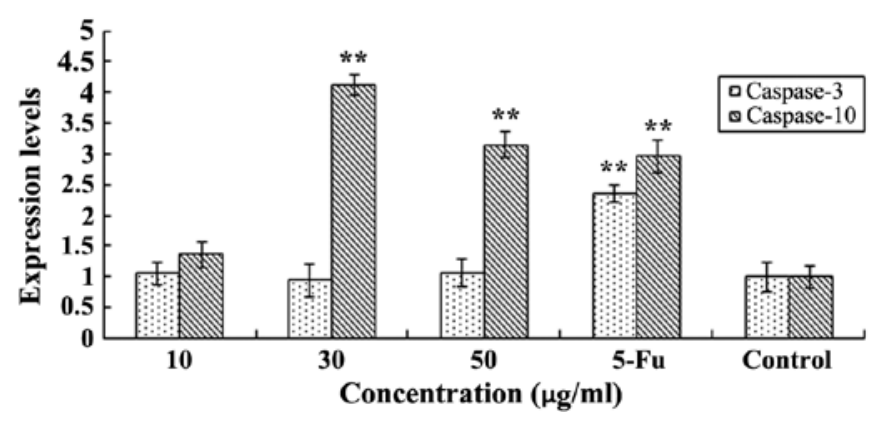

Figure 5. Effect of euptox A blend on mRNA expression of caspase-10 and -3 in HeLa cells. 5-Fu: positive control group; control: $0 \mu / \mathrm{ml}$ euptox A; 10: $10 \mu \mathrm{g} / \mathrm{ml}$ of euptox A group, 30: $30 \mu \mathrm{g} / \mathrm{ml}$ of euptox A group group; 50: $50 \mu \mathrm{g} / \mathrm{ml}$ of euptox A group.

The cell cycle was analysed by flow cytometry at various concentrations of euptox A. Significant differences in the distribution of the cell cycle after various concentration of euptox A were observed following treatment for $24 \mathrm{~h}$ (Figs. 2 and 3) in a dose-dependent manner. Compared with the negative control group, the amount of S-phase cells increased from $31 \%$ to $40.936 \%$ and $48.583 \%$ to $56.950 \%$ at concentrations of 10,30 and $50 \mu \mathrm{g} / \mathrm{ml}$ of euptox A in the experimental control group, respectively. However, for the positive control group, the amount of G1/M phase cells increased from $47.533 \%$ to $54.553 \%$ (Tables II and III). 
Expression of the caspase-10 and -3 genes. Total RNA was extracted from HeLa cell. The total RNA was measured for integrity, purity and yield of RNA met the necessary requirement (Fig. 4). The expression levels of caspase-10 and -3 genes in each group are shown in Fig. 5. The expression levels of caspase-10 gene in HeLa cells were increased following incubation with euptox A for $24 \mathrm{~h}$, but were not dose-dependent. An initial increase followed by a decrease with an increase of the euptox A dose was observed. In addition, higher expression levels of caspase-10 gene following treatment with $30 \mu \mathrm{g} /$ $\mathrm{ml}$ of euptox A were observed. However, in HeLa cells the caspase-3 gene showed only a slight decrease following incubation with euptox A for $24 \mathrm{~h}$. However, in the 5-Fu positive control group, an increase of caspase-10 and -3 gene expression levels following incubation for $24 \mathrm{~h}$ was observed.

\section{Discussion}

Cancer is a common and frequently occurring disease that is a serious threat to human and animal life, its mortality rate is second only to cardiovascular disease. At present, natural anti-neoplastic drugs have become the subject of much investigation. Natural products such as paclitaxel $(19,20)$, camptothecine $(21,22)$, podophyllotoxin $(23)$, matrine (24) and vincristine (25) have been shown to have anticancer activity. As recently demonstrated, euptox A extracted from $E$. adenophorum markedly inhibited the growth of cancer cells directly. Euptox A was found to be highly active against the rapidly growing HeLa cells, and its activity was concentration-dependent. A direct comparison with 5-Fu in the cell lines showed a clear superiority of euptox A, as 5-Fu is an antimetabolite that has been used as a chemotherapeutic agent for a various types of cancer for over 40 years (26). However, the antitumor activity of euptox A was markedly stronger than that of 5-Fu at the same concentration. The reason is most likely that the test tumors were resistant to the 5-Fu. Our findings are consistent with previous studies which have shown that the E. adenophorum had antitumor activity (27).

In the present study, we found that euptox A effectively inhibited the proliferation of HeLa cells, arrest the cell cycle transition from $\mathrm{S}$ to $\mathrm{G} 2 / \mathrm{M}$ phase, did not continue completion of the cell cycle activity (mainly from 4 times and mitosis), and induced cell proliferation. The findings are consistent with those of previous studies, where 10-hydroxycamptothecine (HCPT) showed marked cell cycle specificity in inducing death and apoptosis in the G1 phase, blocking the S phase (28). Caspase-10 is believed to be crucial in initiation of apoptosis by death receptors (29). The caspase-10 gene expression levels in HeLa cells were increased following treatment with euptox A. It is suggested that euptox A resulting in apoptosis may be regulated by influencing caspase-10 gene expression in HeLa cells.

The present study provides a new approach for the utilization of E. adenophorum. Euptox A has the potential to be developed as an antitumor drug. However, future studies are necessary for clinical trials, animal acute toxicity test and safety evaluation.

\section{Acknowledgements}

This study was supported by Science and Technology Support Program of Sichuan Province (grant no. 2015SZ0201), Special
Fund for Agroscientific Research in the Public Interest (grant no. 201203062) and Chang-jiang Scholars and the Innovative Research Team in University (grant no. IRT0848).

\section{References}

1. Lu P, Sang W and Ma K: Progress and prospects in research of an exotic invasive species Eupatorium adenophorum. Acta Phytoecological Sinica 29: 1029-1037, 2005.

2. Lu ZJ and Ma KP: Spread of the exotic croftonweed (Eupatorium adenophorum) across southwest China along roads and streams. Weed Sci 54: 1068-1072, 2006.

3. Sang W,Zhu L and Axmacher JC: Invasion pattern of Eupatorium adenophorum Spreng in southern China. Biol Invasions 12: 1721-1730, 2010.

4. Guo S, Li W, Zhang L, Peng J, Xia H and Zhang S: Kinetics and equilibrium adsorption study of lead (II) onto the low cost adsorbent- Eupatorium adenophorum Spreng. Process Saf Environ 87: 343-351, 2009.

5. Chakravarty AK, Mazumder T and Chatterjee SN: Antiinflammatory potential of ethanolic leaf extract of Eupatorium adenophorum Spreng. Through alteration in production of TNF- $\alpha$, ROS and expression of certain genes. Evid Based Complement Alternat Med 2011: 471074, 2011.

6. Nong X, Ren YJ, Wang JH, Xie Y, Fang CL, Yang DY, et al: Clinical efficacy of botanical extracts from Eupatorium adenophorum against the Sarcoptes scabiei (Sarcoptidae: Sarcoptes) in rabbits. Vet Parasitol 195: 157-164, 2013.

7. Seddiek SA, Khater HF, El-Shorbagy MM and Ali AM: The acaricidal efficacy of aqueous neem extract and ivermectin against Sarcoptes scabiei var. cuniculi in experimentally infested rabbits. Parasitol Res 112: 2319-2330, 2013.

8. Kundu A, Saha S, Walia S, Ahluwalia V and Kaur C: Antioxidant potential of essential oil and cadinene sesquiterpenes of Eupatorium adenophorum. Toxicol Environment Chem 95: 127-137, 2012.

9. Sahoo A, Singh B and Sharma OP: Evaluation of feeding value of Eupatorium adenophorum in combination with mulberry leaves. Livestock Sci 136: 175-183, 2011.

10. Sato $\mathrm{Y}$, Itagak $\mathrm{S}$, Kurokawa $\mathrm{T}$, et al: In vitro and in vivo antioxidant properties of chlorogenic acid and caffeic acid. Int $\mathrm{J}$ Pharm 403: 136-138, 2011.

11. Padalia RC, Bisht DS, Joshi SC and Mathela CS: Chemical composition of the essential oil from Eupatorium adenophorum Spreng. J Essent Oil Res 21: 522-524, 2009.

12. Bhardwaj R, Singh A, Sharma OP, Dawra RK, Kurade NP and Mahato SB: Hepatotoxicity and cholestasis in rats induced by the sesquiterpene, 9-oxo-10,11-dehydroageraphorone, isolated from Eupatorium adenophorum. J Biochem Mol Toxicol 15: 279-286, 2001.

13. Zhu X, Zhang J and Ma K: Soil biota reduce allelopathic effects of the invasive Eupatorium adenophorum. PLoS One 6: e25393, 2011.

14. Liao F, Hu Y, Tan H, et al: Acaricidal activity of 9-oxo-10, 11-dehydroageraphorone extracted from Eupatorium adenophorum in vitro. Exp Parasitol 140: 8-11, 2014.

15. Liao F, Hu Y, Wu L, et al: The antitumor activity in vitro by 9-oxo-10, 11-dehydroageraphorone extracted from Eupatorium adenophorum. Asian J Chem 26: 7321-7323, 2014.

16. Liao F, Wang Y, Huang Y, et al: Isolation and identification of bacteria capable of degrading euptox A from Eupatorium adenophorum Spreng. Toxicon 77: 87-92, 2014.

17. Taher AT, Georgey HH and El-Subbagh HI: Novel 1, 3, 4-heterodiazole analogues: Synthesis and in-vitro antitumor activity. Eur J Med Chem 47: 445-451, 2012.

18. Zhang L, Koyyalamudi SR, Jeong SC, et al: Antioxidant and immunomodulatory activities of polysaccharides from the roots of Sanguisorba officinalis. Int J Biol Macromol 51: 1057-1062, 2012.

19. Xu Q, Liu Y, Su S, Li W, Chen C and Wu Y: Anti-tumor activity of paclitaxel through dual-targeting carrier of cyclic RGD and transferrin conjugated hyperbranched copolymer nanoparticles. Biomaterials 33: 1627-1639, 2012.

20. Khan I, Nisar M, Ahmad M, et al: Molecular simulations of Taxawallin I inside classical taxol binding site of $\beta$-tubulin. Fitoterapia 82: 276-281, 2011.

21. Ramesha B, Suma H, Senthilkumar U, et al: New plant sources of the anti-cancer alkaloid, camptothecine from the Icacinaceae taxa, India. Phytomedicine 20: 521-527, 2013. 
22. Fulzele DP and Satdive RK: Distribution of anticancer drug camptothecin in Nothapodytes foetida. Fitoterapia 76: 643-648, 2005.

23. Qin L, Xue M, Wang W, et al: The in vitro and in vivo anti-tumor effect of layered double hydroxides nanoparticles as delivery for podophyllotoxin. Int J Pharm 388: 223-230, 2010.

24. Zhang JQ, Li YM, Liu T, et al: Antitumor effect of matrine in human hepatoma G2 cells by inducing apoptosis and autophagy. World J Gastroenterol 16: 4281-4290, 2010.

25. Zhang T, Zheng Y, Peng Q, Cao X, Gong T and Zhang Z: A novel submicron emulsion system loaded with vincristine-oleic acid ion-pair complex with improved anticancer effect: in vitro and in vivo studies. Int J Nanomed 8: 1185-1196, 2013.

26. Li F, Wang F, Yu F, et al: In vitro antioxidant and anticancer activities of ethanolic extract of selenium-enriched green tea. Food Chem 111: 165-170, 2008.
27. Yan Q, Yang J,Li H, et al: Advances in the studies on the chemical components and bioactivity of Eupatorium adenophorum Spreng as a intruding species. J Beijing Norm Univ Nat Sci 42: 70-73, 2006 (In Chinese).

28. Jiang S, Tu S and Tan J: Apoptosis in gastric cancer cells induced by hydroxycamptothecine. Chin J Dig 1: 19-21, 1999.

29. Sprick MR, Rieser E, Stahl H, Grosse-Wilde A, Weigand MA and Walczak H: Caspase-10 is recruited to and activated at the native TRAIL and CD95 death-inducing signalling complexes in a FADD-dependent manner but can not functionally substitute caspase-8. EMBO J 21: 4520-4530, 2002. 